\title{
KELAS SOIL DAERAH SEKITAR RENCANA TAPAK REAKTOR DAYA EKSPERIMENTAL (RDE) SERPONG DARI DATA MIKROTREMOR
}

\author{
Marjiyono $^{1}$, Hadi Suntoko ${ }^{2}$, Soehaimi, A. ${ }^{1}$, Yuliastuti ${ }^{2}$, Syaeful, H. ${ }^{3}$ \\ ${ }^{1}$ Pusat Survei Geologi,Badan Geologi, Kementerian Energi dan Sumberdaya Mineral, \\ Jl. Diponegoro No. 57 Bandung 40122, email : marjiyono@emailcorner.net \\ ${ }^{2}$ Pusat Kajian Sistem Energi Nuklir, BATAN, Jl Kuningan Barat, Mampang Prapatan, Jakarta \\ Selatan 12710, email : hadi_suntoko@batan.go.id \\ ${ }^{3}$ Pusat Teknologi Bahan Galian Nuklir, BATAN, Jl. Lebak Bulus Raya No. 9, Pasar Jumat, \\ Jakarta 12440, email: syaeful@batan.go.id
}

\begin{tabular}{|c|c|c|}
\hline Diterima & Diterima dalam bentuk revisi & Disetujui \\
\hline 30 Januari 2015 & 16 April 2015 & 29 April 2015 \\
\hline
\end{tabular}

\begin{abstract}
ABSTRAK
KELAS SOIL DAERAH SEKITAR RENCANA TAPAK REAKTOR DAYA EKSPERIMENTAL (RDE) SERPONG DARI DATA MIKROTREMOR. Karakteristik geologi permukaan memegang peranan penting dalam analisis respon gelombang di suatu wilayah. Sehubungan dengan rencana pembangunan Reaktor Daya Eksperimental (RDE) di Serpong, telah dilakukan pemodelan kondisi bawah permukaan dari kombinasi data mikrotremor array dan single station. Pengukuran mikrotremor array dilakukan di 9 lokasi, sedangkan single station di 90 lokasi yang tersebar pada radius $\pm 1 \mathrm{~km}$ di sekitar tapak RDE. Model bawah permukaan yang berupa struktur kecepatan gelombang geser selanjutnya dijadikan dasar untuk menghitung nilai Vs30 di daerah tersebut. Hasil klasifikasi soil berdasarkan nilai Vs30 menunjukkan kelas soil untuk wilayah sekitar tapak RDE secara umum terdiri atas kelas SD (soil menengah) dan SC (batuan lunak). Lokasi rencana tapak sendiri berada dalam wilayah kelas soil SD.
\end{abstract}

Kata kunci: kelas soil, kecepatan gelombang geser, mikrotremor, tapak RDE, Vs30.

\begin{abstract}
SOIL CLASS AROUND THE SERPONG EXPERIMENTAL POWER REACTOR (EPR) SITE PLAN BASE ON MICROTREMOR DATA. Surface geological characteristics has an important role on site response analysis in a region. In regard with experimental power reactor (EPR) construction plan in Serpong, the subsurface modeling from combination array and single station microtremor data was done. The array and single station microtremor measurement were performed in 9 and 90 sites, respectively, at $\pm 1 \mathrm{~km}$ radius around the EPR site plan. The Vs30 value was calculated from shear wave velocity structure around the investigated area. The soil classification based on Vs30 in the investigated area generally consists of SD (medium soil) and SC (soft rock) class. The EPR site plan its self in the SD class region.

Keyword: soil class, shear wave velocity, microtremor, EPR site, Vs30.
\end{abstract}




\section{PENDAHULUAN}

Pertumbuhan ekonomi selalu berkaitan erat dengan kebutuhan energi. Baik energi fosil (minyak, gas alam dan batu bara) maupun energi listrik. Bila ketersediaan energi tidak mencukupi maka akan mengganggu jalannya perekonomian. Dalam lima tahun ke depan pemerintah memproyeksikan kebutuhan penambahan tenaga listrik sebesar $35.000 \mathrm{Mw}$ dengan mengasumsikan bahwa pertumbuhan kebutuhan listrik per tahun sebesar $9 \%$ atau penambahan daya listrik sebesar $7000 \mathrm{Mw}$ per tahun. Hal ini menjadi tantangan besar bagi pemerintah karena berbagai kendala berkaitan dengan sistem ketenaga listrikan nasional.

Hingga saat ini pembangkitan energi listrik nasional masih bergantung pada energi primer (gas alam, minyak dan batubara) yang kadang mengalami gangguan suplai karena berbagai faktor. Potensi sumber daya energi yang belum tereksploitasi di wilayah tanah air sesungguhnya cukup banyak, diantaranya energi nuklir. Badan Tenaga Nuklir Nasional (BATAN) memperkirakan cadangan spekulatif uranium di Indonesia sekitar 59.200 ton atau setara dengan 6,5 GWe dan thorium sekitar 1500 ton atau setara dengan 1850 MWe untuk operasional 30 tahun $\left[{ }^{[1]}\right.$.

Sehubungan dengan hal tersebut, BATAN berencana membangun Reaktor Daya Eksperimental (RDE) di Serpong, sebagai embrio pemanfaatan energi nuklir di tanah air. Energi nuklir ini diharapkan dapat menjadi solusi kebutuhan energi nasional jangka panjang. Dalam rangka pembangunan tapak RDE, aspek karakteristik dinamik dari soil /sedimen permukaan merupakan salah satu faktor penting dalam evaluasi tapak. Pengamatan geologi bawah permukaan dangkal dengan mikrotremor telah dilakukan di sekitar rencana pembangunan tapak RDE Serpong. Tujuan dari penelitian ini adalah untuk memperkirakan gambaran kondisi bawah permukaan berupa struktur kecepatan gelombang geser yang akan digunakan untuk menghitung nilai Vs30 (kecepatan geombang geser rata-rata asmpai kedalaman $30 \mathrm{~m}$ ) serta jenis soil di daerah penelitian. Parameter Vs30 ini sudah digunakan secara luas dalam evaluasi jenis soil karena berkaitan langsung dengan kelakuan gelombang pada litologi permukaan ${ }^{[2]}$ bahkan sudah dijadikan dasar untuk klasifikasi tanah dalam penentuan kode bangunan ${ }^{[3]}$.

\section{METODOLOGI}

\subsection{Geologi Daerah Penelitian}

Secara morfologi daerah Serpong dan sekitarnya merupakan dataran bergelombang dengan ketinggian antara $80-100 \mathrm{~m}$ dpl. Turkandi, dkk.[5] dalam peta Geologi Lembar Jakarta dan Kepulauan Seribu, skala 1:100.000 menyatakan bahwa daerah Serpong dan sekitarnya ditempati oleh litologi Formasi Bojongmanik, Formasi Genteng, Formasi Serpong, endapan kipas aluvial dan endapan aluvial. Endapan aluvial ini umumnya ditemukan di sekitar aliran sungai. Hasil pengamatan di lapangan, satuan litologi disekitar rencana tapak RDE adalah sebagai berikut :

a. Satuan Batupasir Gampingan, dijumpai berwarna kelabu kehijauan, berbutir halussedang, membundar tanggung-bundar, terpilah baik, berselang-seling dengan batulempung berwarna abu-abu kebiruan. Batuan ini merupakan bagian dari Formasi Bojongmanik. Pada beberapa tempat batuan ini juga ditemukan bersisipan batugamping masif berwarna abu-abu kekuningan, mengandung fosil moluska dan koral. Berdasarkan ciri perlapisan yang baik dengan struktur sedimen lapisan bersusun, silang siur, struktur perarian dan kandungan fosilnya, maka formasi Bojongmanik ini diduga diendapkan dalam lingkungan laut dangkal terbuka, sublitoral dalam. Berdasarkan analisis fosil yang terkandung pada lapisan batulempung menunjukan Formasi ini berumur Miosen Tengah. Batuan ini banyak tersingkap di sepanjang Sungai Cisadane. 
b. Satuan Batupasir tufaan, berwarna abu-abu kebiruan, berbutir sedang hingga kasar, mengandung glaukonit, kuarsa dan kayu terkersikkan. Batuan ini merupakan bagian dari Formasi Genteng, terutama ditemukan di sebelah barat Sungai Cisadane. Menurut Turkandi, dkk. (1992) Formasi Genteng terdiri atas tuf batuapung, batupasir tufaan, breksi, andesit, konglomerat dan sisipan lempung tufaan. Dalam satuan ini terdapat kandungan batuapung, kuarsa, mika dan hornblenda, setempat-setempat dijumpai sisipan tipis tuf debu dan kayu terkersikan. Berdasarkan kedudukan stratigrafinya yang menindih tak selaras Formasi Bojongmanik dan di tindih secara tak selaras oleh Formasi Serpong, maka Formasi Genteng ini diduga berumur Pliosen Awal - Pliosen Tengah. Berdasarkan struktur sedimen dan komposisi batuan penyusunnya, diduga formasi ini diendapkan dalam lingkungan litoral hingga darat.

c. Satuan Konglomerat, berwarna hitam kebiruan sampai coklat muda, terdiri dari aneka ragam komponen, yaitu andesit, basal, batugamping dan rijang, setempat terdapat fosil kayu, matrik pasir hitam, kemas terbuka, pemilahan sedang. Batuan ini merupakan bagian dari Formasi Serpong. Formasi Serpong sendiri tersusun atas perselingan konglomerat, batupasir, batulanau, batulempung dengan sisa tanaman, konglomerat batuapung dan tuf batuapung. Satuan batuan ini pada umumnya mengisi bagian yang tererosi dari batuan yang lebih tua (Formasi Bojongmanik). Di bagian atas konglomerat ini mengandung komponen batuapung yang berukuran lebih kecil $(3-5 \mathrm{~cm})$ dengan matriks pasir tufaan. Berdasarkan kedudukan stratigrafinya yang menindih secara tidak selaras Formasi Bojongmanik dan Formasi Genteng dan ditindih secara tidak selaras oleh endapan kipas aluvial, diduga Formasi Serpong ini berumur Pliosen Akhir. Bila ditinjau dari ketidak adanya fosil, struktur sedimen dan bentuk sebarannya disekitar sungai, maka Formasi Serpong ini diendapkan pada sungai tua yang berpola menganyam dan sebagian diendapkan pada lingkungan rawa. Gambar 1 menunjukkan singkapan batuan Formasi Serpong di sebelah utara komplek Puspitek Serpong.

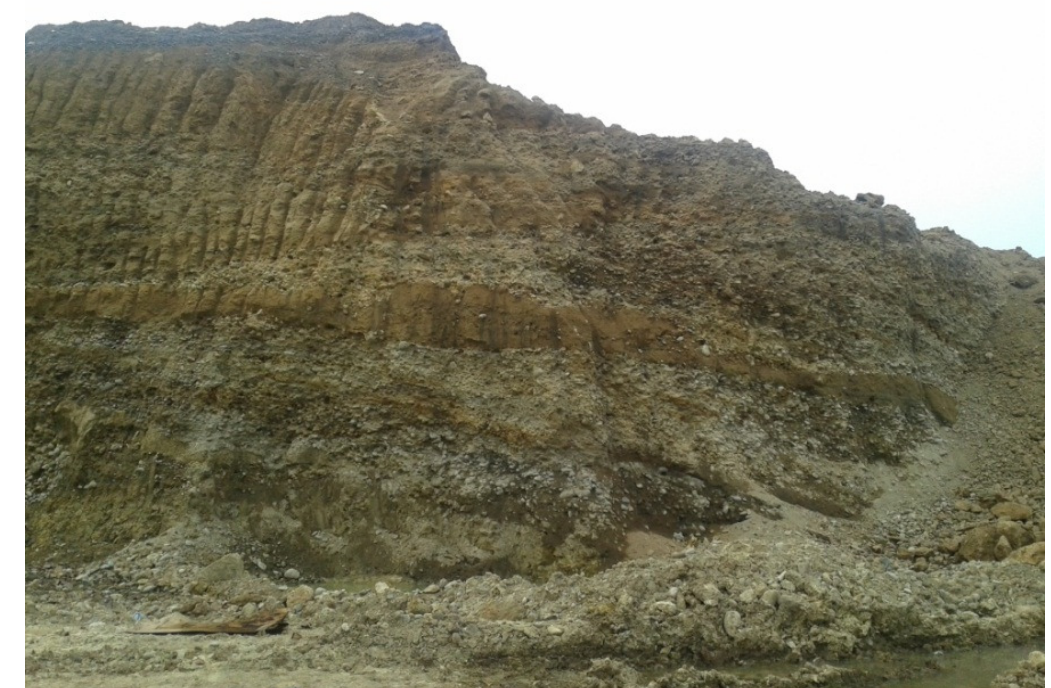

Gambar 1. Singkapan Satuan Konglomerat, perselingan konglomerat, batupasir dan batulanau bagian dari Formasi Serpong.

d. Satuan Tufa, satuan ini merupakan endapan kipas produk Gunung Salak. Endapan ini tersusun atas tufa halus berlapis, tuf pasiran, berselingan dengan tuf konglomeratan. Satuan batuan ini diperkirakan berumur Plistosen hingga Holosen. 
e. Aluvial, dijumpai disepanjang aliran S. Cisadane dan sungai sungai kecil di sekitarnya umumnya berupa endapan sungai sekarang. Secara umum satuan ini terdiri atas lempung, lanau, pasir, kirikil, kerakal dan bongkah batuan beku dan kadang-kadang sedimen yang masif.

\subsection{Pemodelan}

Pemodelan struktur kecepatan gelombang geser di sekitar rencana tapak RDE Serpong ini dilakukan dengan penggabungan dua metode, yakni mikrotremor array dan single station. Pengukuran dilakukan pada 9 lokasi mikrotremor array dan dan 90 lokasi mikrotremor single station yang tersebar pada radius $\pm 1 \mathrm{~km}$ dari rencana tapak RDE (Gambar 2). Pengukuran mikrotremor array dimaksudkan untuk memperoleh struktur kecepatan gelombang geser secara satu dimensi untuk setiap titik ukur, kemudian dilakukan interpolasi sehingga didapatkan gambaran struktur bawah permukaan untuk seluruh wilayah penelitian secara umum. Adapun data mikrotremor single station dimaksudkan untuk memperoleh gambaran sebaran ketebalan sedimen permukaan secara lebih rinci secara lateral.

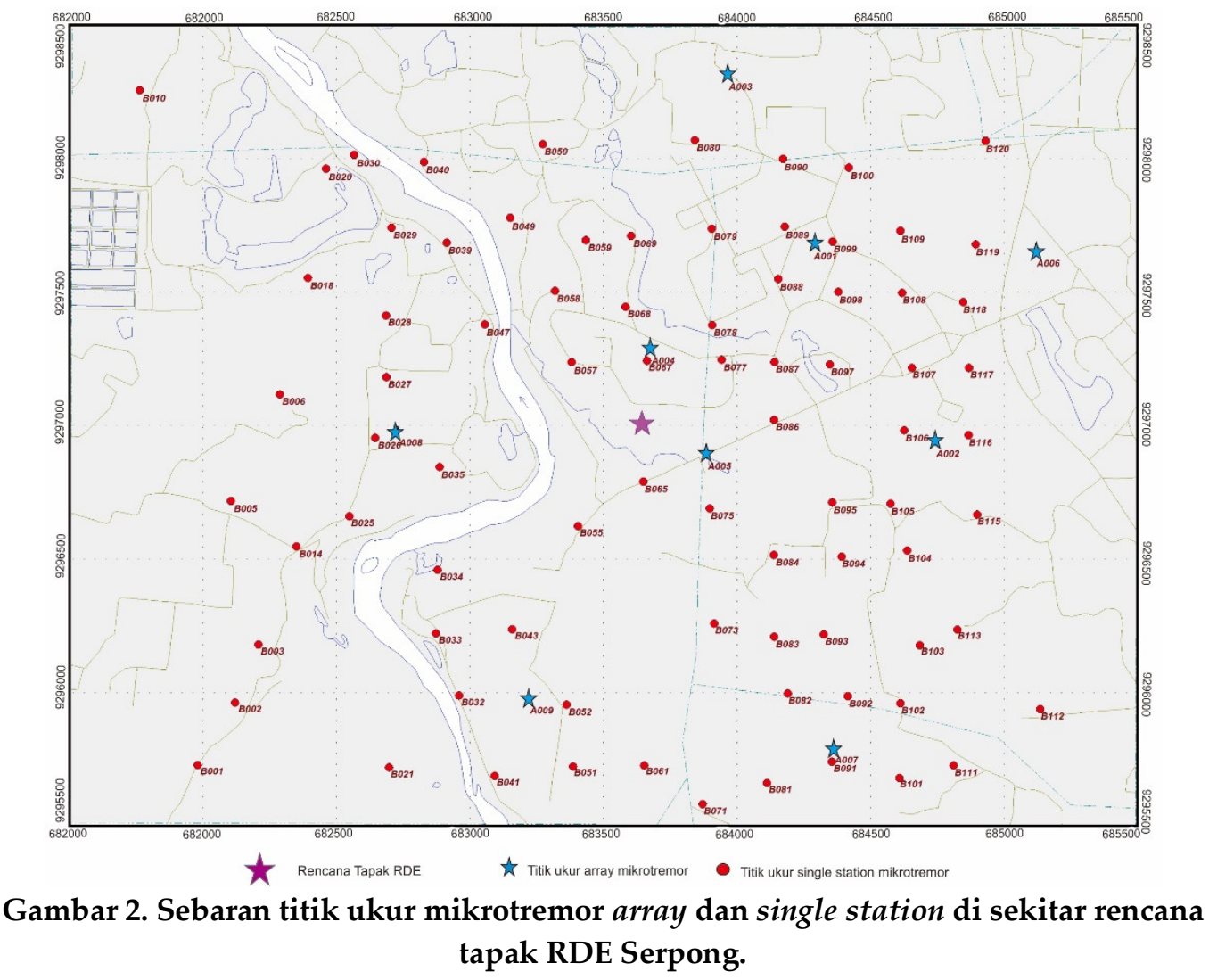

Pengumpulan data mikrotremor array dilakukan dengan peralatan 4 unit OYO McSeis-1134 dengan konfigurasi triangle nested dengan ukuran array dari 2,5 - $50 \mathrm{~m}$. Pengukuran umumnya dilakukan di lapangan-lapangan bola atau tanah tegalan yang datar dan luas. Pengukuran mikrotremor single station dilakukan dengan peralatan seismometer Lennartz 0.2-3D dan direkam dengan data logger SARA SL-06 dengan sampling rate $100 \mathrm{~Hz}$. Adapun pengolahan data dilakukan dengan perangkat lunak Geopsy 2.3 dan HV Explorer.

Pemodelan struktur bawah permukaan gelombang geser ini didasarkan pada formula Aki (1957) yang merumuskan bahwa bila ada dua stasiun pengamatan mikrotremor yang 
merekam secara simultan yang dipisahkan sejauh $\mathrm{r}$ maka besarnya nilai koefisien korelasi adalah :

$$
\rho(r, \omega)=J_{0}\left(\frac{\omega}{c(\omega)} r\right)
$$

dengan:

$$
\begin{array}{ll}
\omega & \text { : frekuensi anguler } \\
\mathrm{J}_{0} & \text { : fungsi Bessel jenis pertama orde nol } \\
\mathrm{c}(\omega) & \text { : kecepatan gelombang permukaan. }
\end{array}
$$

Kecepatan gelombang permukaan $c(\omega)$ bersifat dispersif (fungsi frekuensi). Dari persamaan di atas, bila fungsi $\mathrm{Q}(\mathrm{r}, \omega)$ sudah diketahui maka besarnya kecepatan $\mathrm{c}$ dapat diinversi dari kurva dispersinya. Hasil dari inversi berupa struktur kecepatan gelombang geser satu dimensi (1D). Model ini yang selanjutnya akan digunakan untuk menghitung nilai Vs30. Perhitungan nilai Vs30 didasarkan pada perumusan Borcherdt ${ }^{[9]}$ yang mendefinisikan Vs30 sebagai :

$$
V_{S 30}=\frac{30}{\sum_{i=1}^{n} \frac{h_{i}}{V_{S i}}}
$$

dengan:

$h_{\mathrm{i}} \quad$ : ketebalan lapisan ke i

$\mathrm{V}_{\mathrm{si}} \quad$ : kecepatan gelombang geser lapisan ke i

n : jumlah lapisan.

Adapun klasifikasi soil dalam penelitian ini didasarkan pada SNI 1726 :2012 (lihat Tabel 1).

Tabel 1. Klasifikasi soil / litologi permukaan berdasarkan Vs30 (SNI 1726:2012) ${ }^{[10]}$

\begin{tabular}{lc}
\hline \multicolumn{1}{c}{ Kelas Situs } & Vs30 (m/detik) \\
\hline SA (batuan keras) & $>1500$ \\
SB (batuan) & $750-1500$ \\
SC (tanah keras, soil & $350-750$ \\
masif, batuan lunak) & $175-350$ \\
SD (soil menengah) & $<175$ \\
SE (soil lunak) & $\begin{array}{l}\text { Diperlukan evaluasi } \\
\text { SF (tanah khusus) }\end{array}$ \\
& $\begin{array}{l}\text { khusus untuk } \\
\text { mengidentifikasi jenis } \\
\end{array}$ \\
& soil ini. \\
\hline
\end{tabular}

\section{HASIL DAN PEMBAHASAN}

Efek geologi permukaan terhadap kelakuan gelombang sudah dipahami secara baik oleh para ahli seismologi. Aki dan Richards ${ }^{[11]}$ menyatakan bahwa penguatan gelombang di permukaan (A) berkaitan langsung dengan kecepatan gelombang geser (Vs) dan rapat massa $(\rho)$ media di permukaan. Secara matematik di nyatakan sebagai berikut :

$$
A \sim \frac{1}{\sqrt{V_{s} \rho}}
$$

Bila kondisi litologi permukaan suatu wilayah memiliki kecepatan gelombang geser yang rendah dan atau mempunyai rapat massa yang kecil maka faktor penguatan gelombang akan cenderung tinggi. Dengan demikian sebenarnya klasifikasi jenis soil 
berdasarkan nilai Vs30 secara tidak langsung juga menunjukkan tingkat resiko terhadap faktor penguatan gelombang. Nilai Vs30 secara internasional juga sudah digunakan sebagai dasar dalam klasifikasi jenis soil[12.13]. Di Indonesia, klasifikasi soil berdasarkan SNI 1726:2012 terdiri atas 6 tingkatan. Tipe soil SA merupakan tingkat paling aman, sedangkan tipe F merupakan tingkat paling beresiko.

Hasil pemodelan data mikrotremor array di 9 lokasi secara umum menunjukkan hasil yang baik yang ditunjukkan oleh nilai misfit yang kecil. Contoh profil kecepatan gelombang geser 1D hasil pemodelan pada titik ukur A001 dapat dilihat pada Gambar 3. Hasil pemodelan di titik ukur A001 tersebut menunjukkan terdapat dua lapis litologi dengan lapisan permukaan mempunyai kecepatan gelombang geser $177 \mathrm{~m} / \mathrm{dt}$, sedangkan lapisan di bawahnya mempunyai kecepatan $900 \mathrm{~m} / \mathrm{dt}$. Ketebalan lapisan permukaan sekitar $17 \mathrm{~m}$. Bila diamati dari litologi permukaan sekitar Komplek Puspitek Serpong berupa soil lapukan dari batupasir berwana kecoklatan, lapisan permukaan tersebut merupakan Formasi Serpong, sedangkan lapisan yang mengalasinya bila ditinjau dari nilai kecepatan gelombang gesernya merupakan batuan yang cukup masif, yang diperkirakan merupakan batuan Formasi Bojongmanik. Secara keseluruhan dari pemodelan di 9 titik ukur array mikrotremor, nilai kecepatan gelombang geser lapisan permukaan berkisar antara $160 \mathrm{~m} / \mathrm{dt}$ hingga $253 \mathrm{~m} / \mathrm{dt}$. Adapun hasil interpolasi nilai kecepatan gelombang geser pada lapisan permukaan dapat dilihat pada Gambar 4.

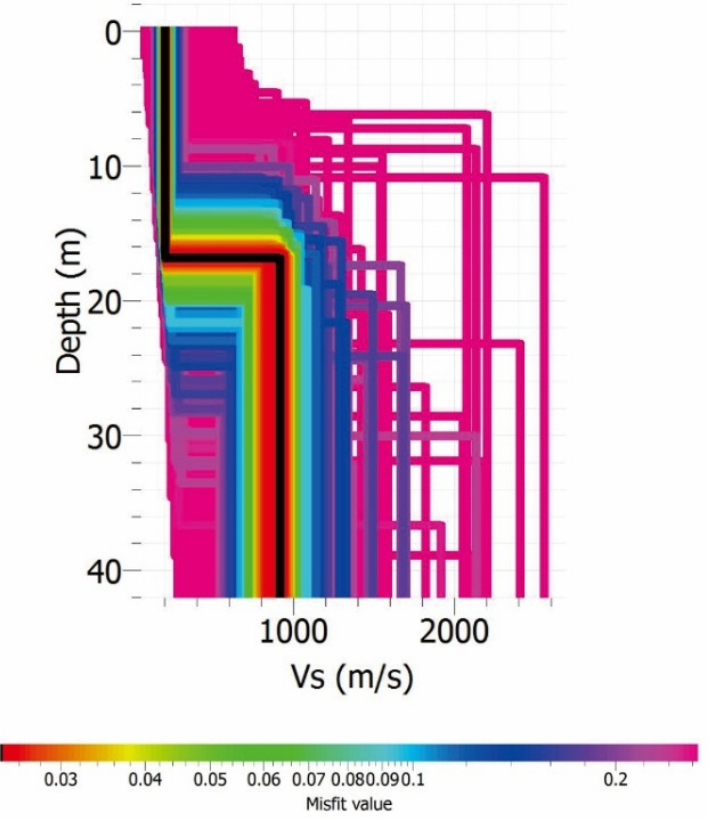

Gambar 3. Profil struktur kecepatan gelombang geser pada titik ukur A001.

Pola sebaran kecepatan gelombang geser lapisan permukaan (Gambar 4) menunjukkan secara umum daerah penelitian mempunyai kecepatan gelombang seser di atas $200 \mathrm{~m} / \mathrm{dt}$. Zona berkecepatan gelombang geser rendah berada di sebelah timur rencana tapak RDE dan memanjang ke arah tenggara. Di sebelah timur Sungai Cisadane, litologi umumnya batupasir Formasi Serpong dan beberapa tempat berupa aluvial, sedangkan di sebelah barat sungai umumnya berupa batupasir tufaan Formasi Genteng. Adapun ketebalan lapisan permukaan ini dapat dilihat pad Gambar 5.

Bila ditinjau dari pola cekungan pada Gambar 5, maka zona berkecepatan gelombang geser rendah pada Gambar 4 merupakan material pengisi cekungan yang berada di bagian tenggara dari daerah penelitian. 


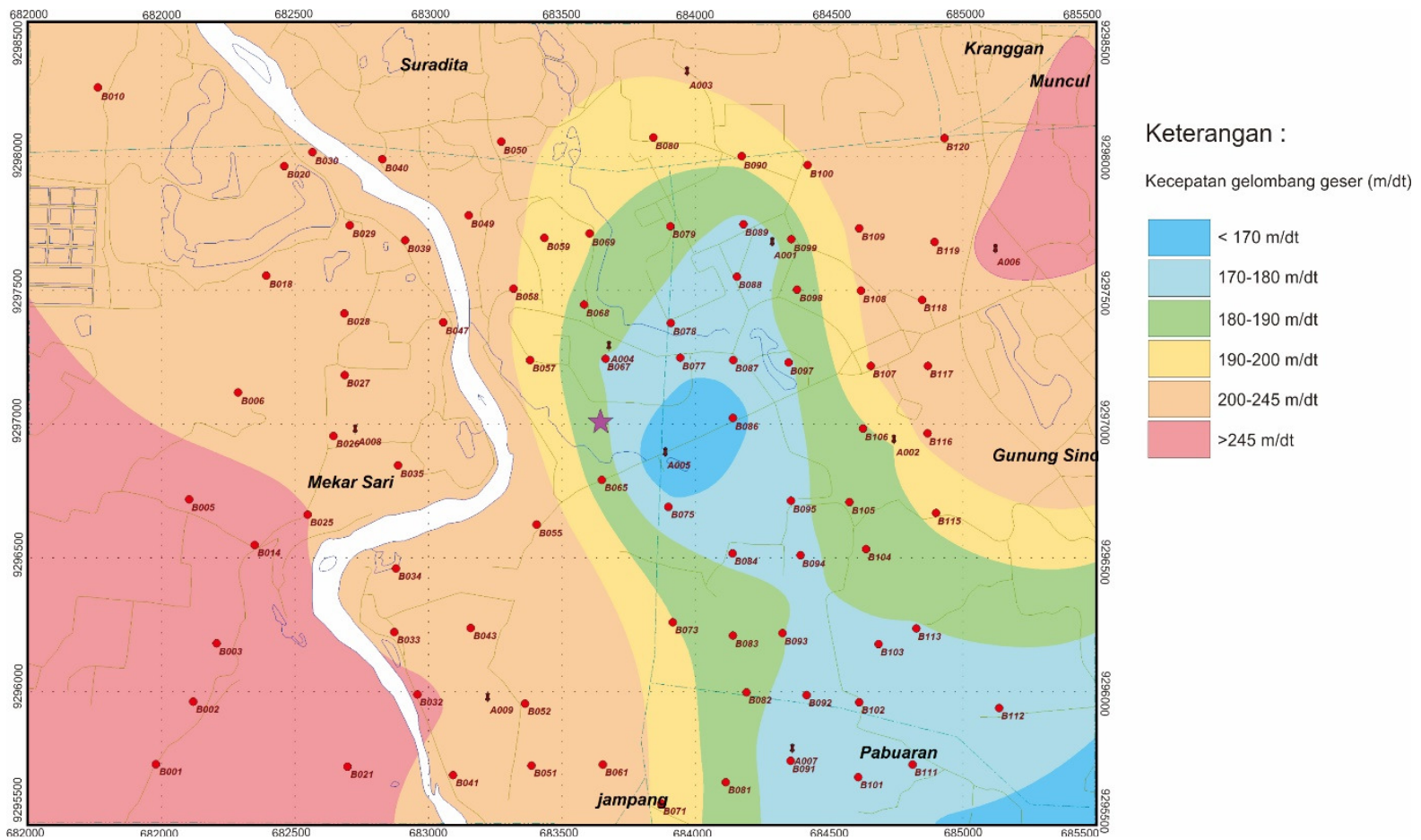

Gambar 4. Sebaran kecepatan gelombang geser lapisan permukaan daerah

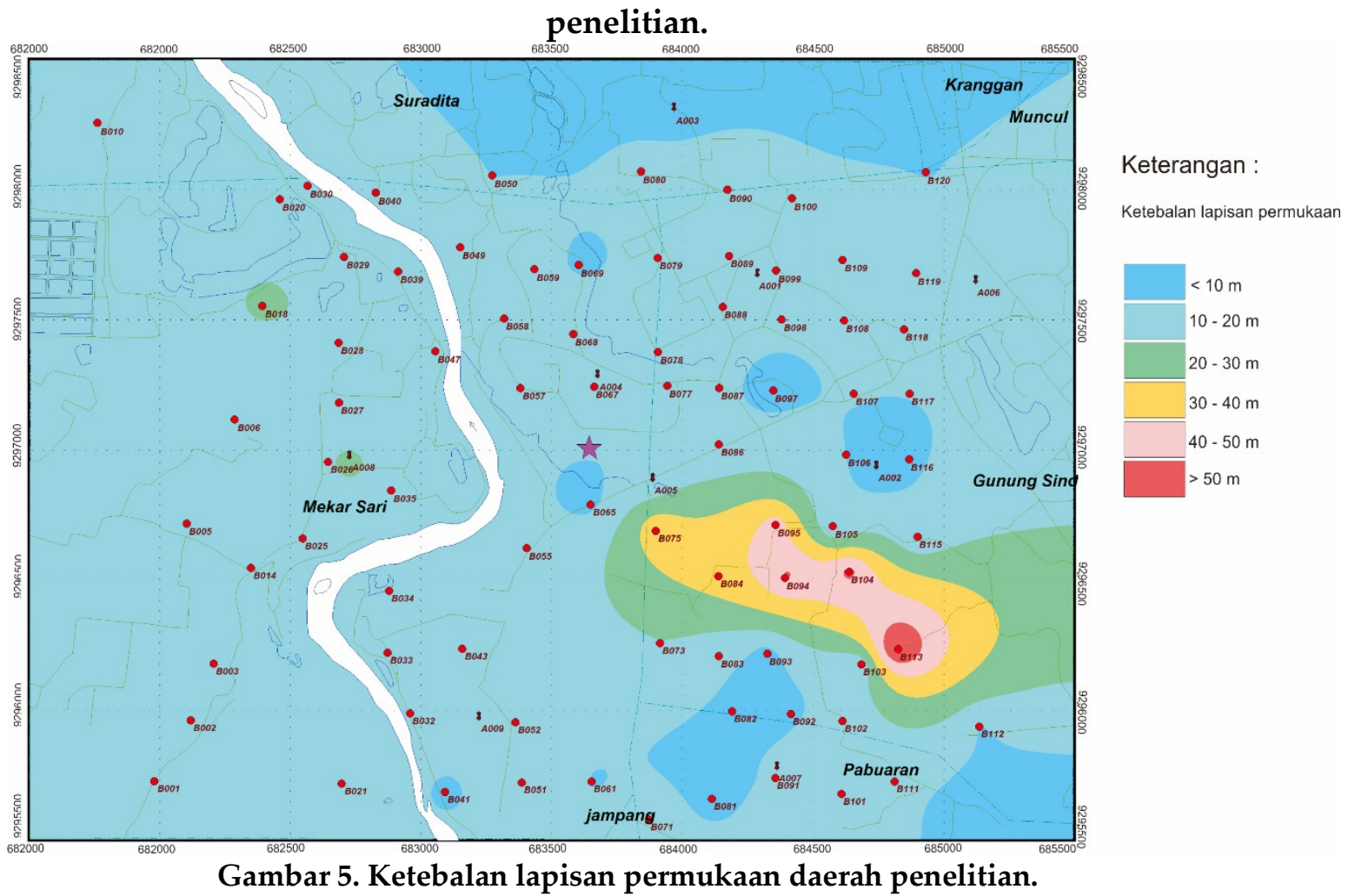

Hasil pemodelan lapisan II (yang mengalasi lapisan permukaan) berkisar antara 493 $\mathrm{m} / \mathrm{dt}$ hingga $900 \mathrm{~m} / \mathrm{dt}$ diperkirakan merupakan batuan Formasi Bojongmanik yang ditumpangi secara tidak selaras oleh Formasi Serpong dan Foarmasi Genteng. Hasil interpolasi nilai kecepatan gelombang geser untuk seluruh daerah penelitian ditunjukkan 
pada Gambar 6. Secara umum pola sebaran kecepatan gelombang geser lapisan ini menunjukkan pola gradual meninggi ke arah utara. Bila ditinjau dari nilai kecepatan gelombang gesernya litologi pada bagian selatan umumnya relatif lunak. Cekungan yang berada di sebelah tenggara rencana tapak RDE tampaknya masih memberi pengaruh pada litologi lapisan II yang ditunjukkan oleh pola zona kecepatan gelombang geser yang relatif rendah.

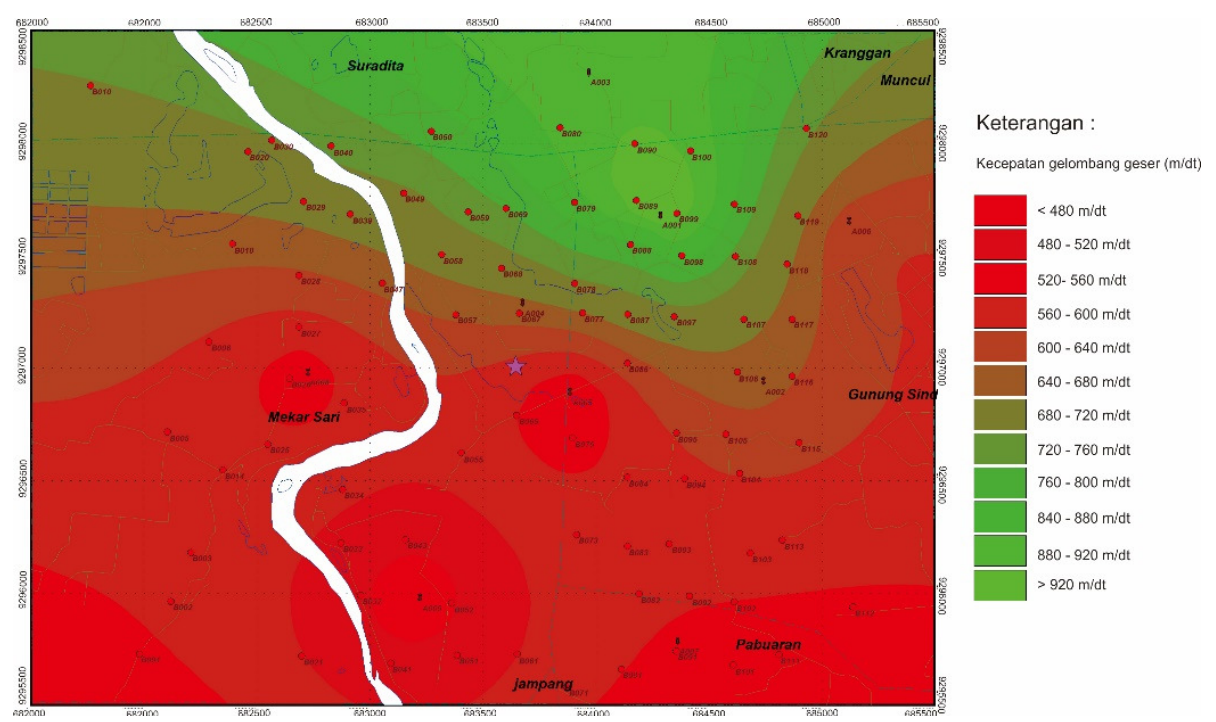

Gambar 6. Sebaran kecepatan gelombang geser lapisan II daerah penelitian.

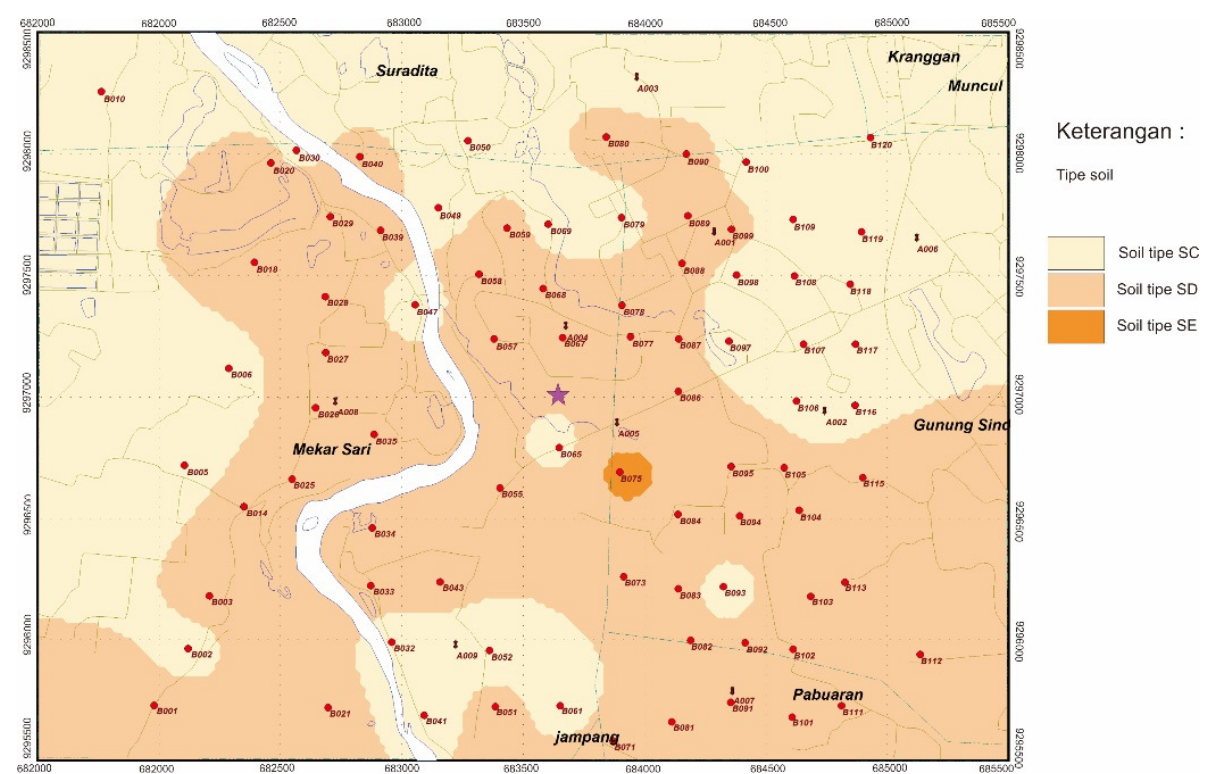

Gambar 7. Kelas soil sekitar rencana tapak RDE Serpong berdasarkan SNI 1726:2012.

Dari data nilai ketebalan lapisan permukaan dan nilai kecepatan gelombang geser untuk kedua lapisan tersebut di atas, maka dapat dihitung nilai Vs30 untuk seluruh daerah penelitian. Nilai ini selanjutnya diklasifikasikan untuk memperoleh kelas soil seluruh daerah penelitian berdasarkan SNI 1726:2012. Gambar 7 memperlihatkan kelas soil daerah sekitar rencana tapak RDE Serpong. 
Secara umum daerah penelitian mempunyai kelas soil SC dan SD atau kelas soil menengah hingga batuan lunak, kecuali sedikit di daerah sekitar cekungan di sebelah tenggara rencana tapak RDE. Lokasi rencana tapak RDE sendiri berada pada kelas soil SD.

\section{KESIMPULAN DAN SARAN}

Vs30 menjadi parameter yang penting dalam penilaian resiko akibat penguatan gelombang oleh litologi permukaan, terutama pada wilayah yang mempunyai seismisitas yang tinggi. Hasil perhitungan nilai Vs30 di sekitar rencana tapak RDE Serpong menunjukkan bahwa secara umum daerah ini mempunyai kelas soil SC dan SD atau kelas soil menengah hingga batuan lunak. Rencana lokasi tapak RDE sendiri berada pada kelas soil SD. Hasil pemodelan data mikrotremor hingga kedalaman $30 \mathrm{~m}$ menunjukkan daerah penelitian secara umum terdiri dari dua lapis litologi, dengan kecepatan gelombang geser lapisan permukaan berkisar antara $160 \mathrm{~m} / \mathrm{dt}$ hingga $253 \mathrm{~m} / \mathrm{dt}$. Lapis kedua diperkirakan merupakan batuan Formasi Bojongmanik dengan kisaran kecepatan gelombang geser antara $493 \mathrm{~m} / \mathrm{dt}$ hingga $900 \mathrm{~m} / \mathrm{dt}$. Dari pola ketebalan lapisan permukaan juga ditemukan adanya cekungan di bagian tenggara daerah penelitian yang terisi oleh material berkecepatan gelombang geser relatif rendah.

\section{SARAN}

Dalam penelitian ini kondisi topografi dianggap datar, untuk penelitian selanjutnya pemodelan bawah permukaan perlu memperhitungkan ketinggian setiap titik ukur.

\section{UCAPAN TERIMA KASIH}

Terima kasih kami sampaikan kepada Kepala Pusat Survei Geologi yang telah mengijinkan kami melakukan penelitian mikrotremor di daerah Serpong ini. Terima kasih juga kami sampaikan kepada Kepala Pusat Kajian Sistem Energi Nuklir serta para kolega kami dari PKSEN yang telah banyak membantu dari segi nonteknis serta kepada Dr. Malte $\mathrm{Ib}$-von Seht atas bantuan perangkat lunak untuk pengolahan data mikrotremor.

\section{DAFTAR PUSTAKA}

[1]. BATAN, "Draft Outlook Energi Nuklir Indonesia 2014", Badan Tenaga Nuklir Nasional, Jakarta, 2014.

[2]. IDRISS, I. M., "Response of Soft Soil Sites During Earthquake", Proc. of H. Bolton Seed Memorial Symp., Vol. 2, BiTechPublishers Ltd., Richmond, British Columbia, Canada, pp. 273-289, 1990.

[3]. BUILDING SEISMIC SAFETY COUNCIL (BSSC), "NEHRP Recommended Provisions for Seismic Regulations for New Buildings and Other Structures", Federal Emergency Management Agency, FEMA P-749, Building Seismic Safety Council Washington, D.C, 2010.

[4]. INTERNATIONAL CODES COUNCIL, INC. (ICC), 2000, International Building Code (IBC), Falls Church, VA, 679p, 2000.

[5]. TURKANDI.T, SIDARTO, AGUSTYANTO,D.A, dan HADIWIDJOYO, M.M, "Peta Geologi Lembar Jakarta dan Kepulauan Seribu, Jawa", P3G, Bandung, 1992.

[6]. QUIPE, S., et al., "Estimation of S-Wave Velocity Profiles at Lima City, Peru Using Microtremor Arrays", Journal of Disaster Research Vol.9 No.6, p931-939, 2014.

[7]. NISHIKAWA, H. \& TAKATANI, T., "Evaluation of Predominant Period of Ground Surfae Layer Using Microtremors in Maizuru City", Proceeding of the International 
Conference on Civil Engineering, Energy and Environment, p175-182, Hongkong, 2014.

[8]. AKI, K., "Space and time spectra of stationary stochastic waves, with special reference to microtremors", Bull. Earthquake Res. Inst. 35,415-456, 1957.

[9]. BORCHERDT, R. D., "Estimates of Site-Dependent Response Spectra for Design (Methodology and Justification)", Earthquake Spectra, Vol. 10, No. 4, pp. 617-653, 1994.

[10]. PUSLITBANG PU, "SNI 03 1726-2012 Tata Cara Perencanaan Ketahanan Gempa untuk Bangunan Gedung", Kementrian Pekerjaan Umum, Jakarta 2012.

[11]. AKI, K. and RICHARDS, P.G., Quantitative Seismology, 2nd Edition, University Science Books, 2002.

[12]. MUCCIARELlI, M., GALliPOLI, M. R., "Comparison Between Vs30 and Other Estimates of Site Amplification in Italy", Proceeding of the First European Conference on Earthquake Engineering and Seismology, Geneva, Switzerland, 38 September 2006, Paper No.270, Geneva, 2006.

[13]. PITILAKIS, K., GAZEPIS, C., \& ANASTASIADIS, A., "Design Response Spectra and Soil Classification for Seismic Code Provisions", Proceeding of the 13th World Conference on Earthquake Engineering, Paper No. 2904, Vancouver, B.C., Canada, 2004. 